JSCM T

Journal of Sustainable Construction Materials and Technologies
Journal of Sustainable Construction Materials and Technologies

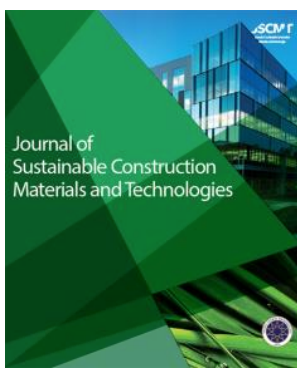

e-ISSN: 2458-973X

https://jscmt.org/

Research Article

\title{
Investigation of Mechanical and Permeability Properties of Fiber Mortars
}

\author{
Veysel Akyüncü̈ ${ }^{\mathrm{a}, *, \text { (]) }}$ \\ ${ }^{a}$ Department of Civil Engineering, Corlu, Tekirdag Namik Kemal University, Tekirdag, Turkey, 59860
}

\begin{abstract}
Concrete is a brittle material which has a higher compressive strength compared to its tensile strength. Steel, glass or polymer fibers are usually added to concrete in order to improve the ductility under mechanical loads. One of the most important factors taken into consideration in producing a durable concrete is by imperviousness concrete. In this study, the mechanical and permeability properties of fiber reinforced mortars were investigated. For this purpose, in addition to the reference, $0.1 \%, 0.2 \%$ by volume, glass fiber reinforced and $1.15 \%$ and $2 \%$ impermeability admix incorporated series were prepared. The effective water/cement ratio of all produced mortar samples was determined to be 0.5 . The workability, ultrasonic pulse velocity (UPV), flexural strength, compressive strength, splitting tensile strength, determination of water penetration depth under pressure were determined in all series. According to the test results, as the glass fiber ratio increased, the water penetration depth decreased by $15 \%$ compared to the reference. In the series where $0.2 \%$ glass fiber was used, there was a $20 \%$ increase compared to the reference in terms of splitting tensile strength. In addition, there is an increase in splitting tensile strength in series produced using glass fiber and impermeability additive.
\end{abstract}

Keywords: Mechanical Properties; Compressive Strength; Fiber Glass; Splitting Tensile Strength; Permeability

\section{Introduction}

Concrete; It is a three-phase heterogeneous material consisting of aggregate, cement paste and the interface of these two components. Aggregate cement paste interface is known as the weakest link in concrete. The formation of cracks at the aggregate-paste interfaces plays an important role in the inelastic behavior of concrete. Studies where microcracks start in the coarse aggregate and the mortar surrounding it and crack propagation takes place at the interface point to the importance of this phase of concrete [1,2]. For this reason, the improvement in mortar properties makes a very important contribution to the strength and durability properties of concrete [3]. Glass, steel and polypropylene fibers, which have a certain length / diameter (slender ratio) ratio, are widely used in order to improve concrete properties positively. Homogeneously dispersed fibers prevent the cracks that occur in the concrete and contribute positively to the strength and durability of the concrete by slowing the progress of the cracks in the concrete. In addition, the energy absorption capacity of concrete can be increased by using fiber in concrete [4].

Today, steel and polymer fibers are widely used in fiber concrete production. However, in recent studies, glass, basalt etc. are used as an alternative to these fibers. There is also an increase in studies with fibers [5-7]. Some features that fibers bring to the fresh mixture; It can be expressed as shrinkage, induced plastic crack formation, segregation, permeability and consistency reduction. Fibers increase the toughness and impact toughness of the hardened mixture, surface wear resistance, fatigue resistance, chemical resistance, fragmentation resistance and freeze-thaw cycle resistance [8-10]. In spite of the great interest in

\footnotetext{
This paper was recommended for publication in revised form by Editor Xiaojian Gao

* Corresponding author/E-mail address: vakyuncu@nku.edu.tr. (V. Akyüncü)

https://doi.org/10.29187/jscmt.2021.57

Received 27 February, 2021; Received in revised form 17 March, 2021; Accepted 20 March, 2021,

Available online 31 March 2021
} 
polymer composites usage in construction, concrete is still the main building material. For this material, there has been a significant amount of research from involvement of modifications to the use of glass fiber as well [11-13]. Compared to nonmodified concrete, glass fiber modified concrete showed better results in mechanical performance and properties as reported by Sanjeev and Sai Nitesh [14]. The increase in compressive, splitting tensile strength, and flexural strength in combination with decrease in slump fall were noticed.

Durability and permeability in concrete are two closely related events. Permeability of concrete; pressurized water is realized by capillary water absorption and steam. If the necessary precautions are not taken in terms of impermeability, this three permeability in concrete reach high values in the same direction and negatively, and this leads to problems in terms of durability. It is extremely important that the concrete to be used in areas exposed to water or moisture is suitable for environmental conditions. Although insulation materials are used in such areas, the risk of exposure to moisture and corrosion is high. The effect of corrosion on structures is devastating. Impermeable concretes protect steel reinforcement against corrosion and external influences [15,16].

In this study, the effect of glass fiber and impermeability additives used in different proportions by keeping sand, water and cement constant on mechanical and permeability properties was investigated. it is aimed to $0.1 \%, 0.2 \%$ by volume, glass fiber reinforced and $1.15 \%$ and $2 \%$ impermeability admix incorporated series were prepared. This objective is supported by various tests such as workability, UPV, flexural strength, compressive strength, splitting tensile strength, determination of water penetration depth under pressure.

\section{Experimental Study}

\subsection{Materials and Mix Proportions}

Powdered crystalline impermeability additive with a density of $1.04 \mathrm{~g} / \mathrm{cm}^{3}, 24 \mathrm{~mm}$ glass fiber, standard Rilem sand and CEM I $42.5 \mathrm{R}$ cement were used. Water / binder ratio was chosen as 0.5 in the productions. In addition to the reference, $0.1 \%$, $0.2 \%$ glass fiber ratio, $1.15 \%$ and $2 \%$ impermeability additives, a total of 9 batchs production were made, with fibrous and impermeability additives. Fiber ratios were used by volume, and impermeability additive was used as percentage of cement by weight. Mortars were cured in $20 \pm 1^{\circ} \mathrm{C}$ lime saturated water in accordance with the TS EN 196-1 [17] standard and subjected to mechanical tests at the of 28 days. Properties of cement and glass fiber used in mortar production are given in Tables 1 and 2. Standard CEN reference sand was used as aggregate. Table 3 shows the properties of the CEN reference sand.

Tablo 1. Chemical, physical and mechanical properties of cement

\begin{tabular}{ll}
\hline Components (\%) & CEM I 42.5 R \\
\hline $\mathrm{CaO}$ & 64.12 \\
$\mathrm{SiO}_{2}$ & 20.23 \\
$\mathrm{Al}_{2} \mathrm{O}_{3}$ & 5.09 \\
$\mathrm{Fe}_{2} \mathrm{O}_{3}$ & 3.34 \\
$\mathrm{MgO}$ & 1.15 \\
$\mathrm{SO}_{3}$ & 2.98 \\
$\mathrm{Na}_{2} \mathrm{O} / \mathrm{K}_{2} \mathrm{O}$ & $0.1 / 0.74$ \\
$\mathrm{Cl}^{-}$ & 0.0324 \\
Loss of ignition & 2.45 \\
Insoluble residue & 0.78 \\
$\mathrm{Physical}$ and mechanical properties of cement \\
\hline Specific gravity & 3.06 \\
Specific surface (cm $\left.{ }^{2} / \mathrm{g}\right)$ & 3520 \\
Initial setting time & 185 \\
(min) & \\
Final setting time (min) & 250 \\
7 days (MPa) & 46.9 \\
\hline 28 days (MPa) & 59.9 \\
\hline
\end{tabular}

Tablo 2. Properties of glass fiber 


\begin{tabular}{ccccc}
\hline $\begin{array}{c}\text { Length } \\
(\mathrm{mm})\end{array}$ & $\begin{array}{c}\text { Density } \\
\left(\mathrm{g} / \mathrm{cm}^{3}\right)\end{array}$ & $\begin{array}{c}\text { Tensile } \\
\text { strength } \\
(\mathrm{MPa})\end{array}$ & $\begin{array}{c}\text { Modulus of } \\
\text { elasticity } \\
(\mathrm{MPa})\end{array}$ & $\begin{array}{c}\text { Diameter } \\
(\mu \mathrm{m})\end{array}$ \\
24 & 2.6 & 3400 & 77000 & 14 \\
\hline
\end{tabular}

Table 3. Particle size distribution of CEN standard sand

\begin{tabular}{llcccccc}
\hline $\begin{array}{l}\text { Sieve size }(\mathrm{mm}) \\
\begin{array}{l}\text { Aggregate remaining } \\
\text { sieve }(\%)\end{array}\end{array}$ & $\begin{array}{c}2.00 \\
\text { in the }\end{array}$ & 0 & 1.60 & 1.00 & 0.50 & 0.16 & 0.08 \\
\hline
\end{tabular}

\subsection{Sample Preparation, Curing and Testing Procedure}

Production of mortar samples was carried out in Tekirda ̆ Namık Kemal University Çorlu Engineering Faculty Building Materials Laboratory. 27 different mixes were prepared. A total of 243 prism and 27 cube mortar samples, were cast. Table 4 gives the details on how the samples were coded.

Table 4. Sample coding

\begin{tabular}{|c|c|}
\hline Sample code & Definition \\
\hline REF-\%0-\%0 & Reference specimens cured in water until testing day \\
\hline L24-\%0,1-\%0 & $24 \mathrm{~mm}$ fiber length $-\% 0,1$ glass fiber ratio $-\% 0$ admixture ratio \\
\hline $\mathrm{L} 24-\% 0,2-\% 0$ & $24 \mathrm{~mm}$ fiber length $-\% 0,2$ glass fiber ratio $-\% 0$ admixture ratio \\
\hline L24-\%0-\%1,15 & $24 \mathrm{~mm}$ fiber length $-\% 0$ glass fiber ratio $-\% 1,15$ admixture ratio \\
\hline $\begin{array}{c}\text { L24-\%0,1- } \\
\% 1,15\end{array}$ & $24 \mathrm{~mm}$ fiber length $-\% 0,1$ glass fiber ratio $-\% 1,15$ admixture ratio \\
\hline $\begin{array}{c}\text { L24-\%0,2- } \\
\% 1,15\end{array}$ & $24 \mathrm{~mm}$ fiber length $-\% 0,2$ glass fiber ratio $-\% 1,15$ admixture ratio \\
\hline $\mathrm{L} 24-\% 0-\% 2$ & $24 \mathrm{~mm}$ fiber length $-\% 0$ glass fiber ratio $-\% 2$ admixture ratio \\
\hline $\mathrm{L} 24-\% 0,1-\% 2$ & $24 \mathrm{~mm}$ fiber length $-\% 0,1$ glass fiber ratio $-\% 2$ admixture ratio \\
\hline $\mathrm{L} 24-\% 0,2-\% 2$ & $24 \mathrm{~mm}$ fiber length $-\% 0,2$ glass fiber ratio $-\% 2$ admixture ratio \\
\hline
\end{tabular}

\section{Results and Discussion}

\subsection{Mechanical properties}

Flow diameter, UPV, flexural strength, compressive strength, splitting tensile strength, permeability test results are given in Table 5.

Table 5. Mechanical and physical properties of the mixtures

\begin{tabular}{|c|c|c|c|c|c|c|}
\hline Mixtures & $\begin{array}{l}\text { Flow } \\
\text { diameter } \\
(\mathrm{mm})\end{array}$ & $\begin{array}{c}\text { UPV } \\
(\mathrm{mm} / \mu \mathrm{s})\end{array}$ & $\begin{array}{c}\text { Flexural } \\
\text { strength }(\mathrm{MPa})\end{array}$ & $\begin{array}{l}\text { Compressive } \\
\text { strength (MPa) }\end{array}$ & $\begin{array}{l}\text { Splitting Tensile } \\
\text { Strength (MPa) }\end{array}$ & $\begin{array}{c}\text { Pressure water } \\
\text { Processing } \\
\text { Depth }(\mathrm{mm})\end{array}$ \\
\hline REF-\%0-\%0 & 17.92 & 4.48 & 11.48 & 41.37 & 3.60 & 12.33 \\
\hline L24-\%0,1-\%0 & 15.98 & 4.45 & 11.45 & 39.83 & 4.07 & 11.66 \\
\hline L24-\%0,2-\%0 & 14.67 & 4.43 & 11.69 & 39.79 & 4.35 & 10.67 \\
\hline L24-\%0-\%1,15 & 16.30 & 4.51 & 11.14 & 34.48 & 5.50 & 12.00 \\
\hline $\begin{array}{l}\text { L24-\%0,1- } \\
\quad \% 1,15\end{array}$ & 14.92 & 4.53 & 12.16 & 27.34 & 6.07 & 15.00 \\
\hline $\begin{array}{l}\text { L24-\%0,2- } \\
\% 1,15\end{array}$ & 13.83 & 4.50 & 11.86 & 27.31 & 5.89 & 11.00 \\
\hline L24-\%0-\%2 & 15.18 & 4.48 & 11.21 & 34.43 & 5.48 & 17.33 \\
\hline L24-\%0,1-\%2 & 13.50 & 4.37 & 9.92 & 14.80 & - & - \\
\hline L24-\%0,2-\%2 & 13.28 & 4.48 & 11.24 & 14.90 & - & - \\
\hline
\end{tabular}




\subsubsection{Workability}

The flow diameters of the mortar samples are shown in Figure 1. The flow diameters vary between $13-18 \mathrm{~cm}$. When Figure 1 . is examined, the spreading diameter decreased as the fiber ratio and impermeability contribution increased. Karahan and Atis [18] and Shekarchi et.al [19] reported that inclusion of polypropylene fiber reduced workability and increase in fiber content caused additional reductions in workability.

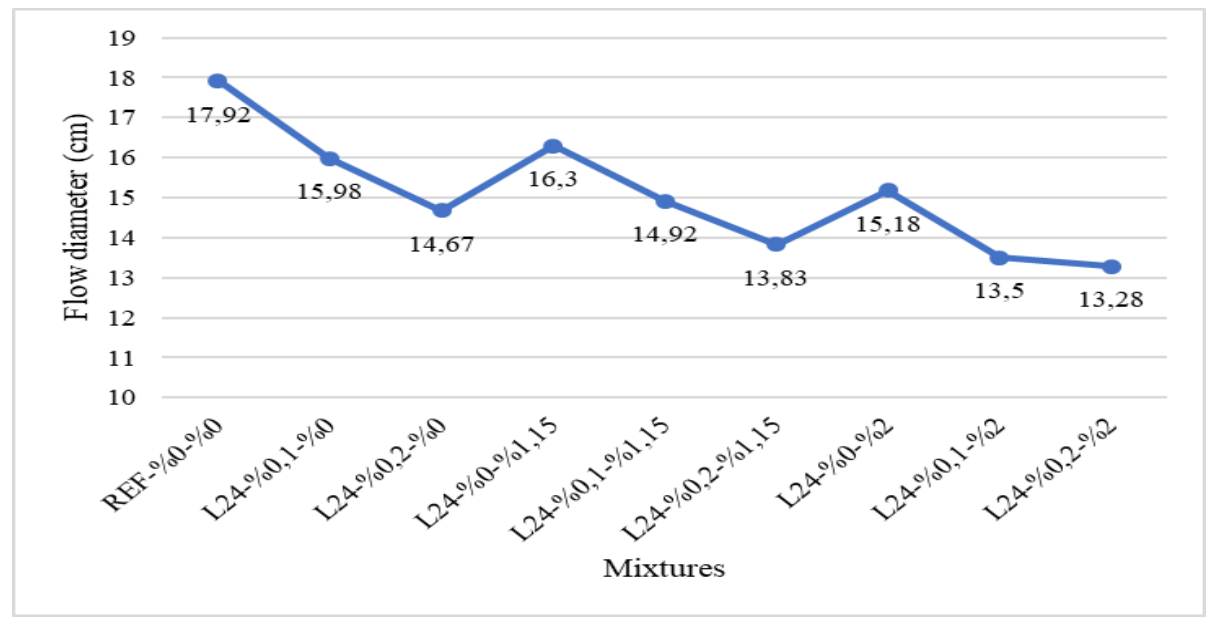

Figure 1. Results of flow diameter

\subsubsection{Compressive strength and Flexural strength}

The graph of the change in the tensile strength and compression strength in bending is given in Figure 2. At the reference with the highest compressive strength, $41.37 \mathrm{MPa}$ was the lowest value, and $14.90 \mathrm{MPa}$ in the series L24- $0.1 \%-2 \%$. As the fiber ratio and water impermeability additives increased in L24- $0.1 \%-2 \%$ and L24-0.2\% $-2 \%$ series, a decrease in compressive strength was observed. Similar results were reported by several researchers [20-21]. Flexural strength gave close values in all series. Bhargava et al. [22] stated that the 4\% decrease in compressive strength, 14\% decrease in splitting tensile strength, and $13 \%$ in flexural strength for concrete modified with glass fibers was obtained.

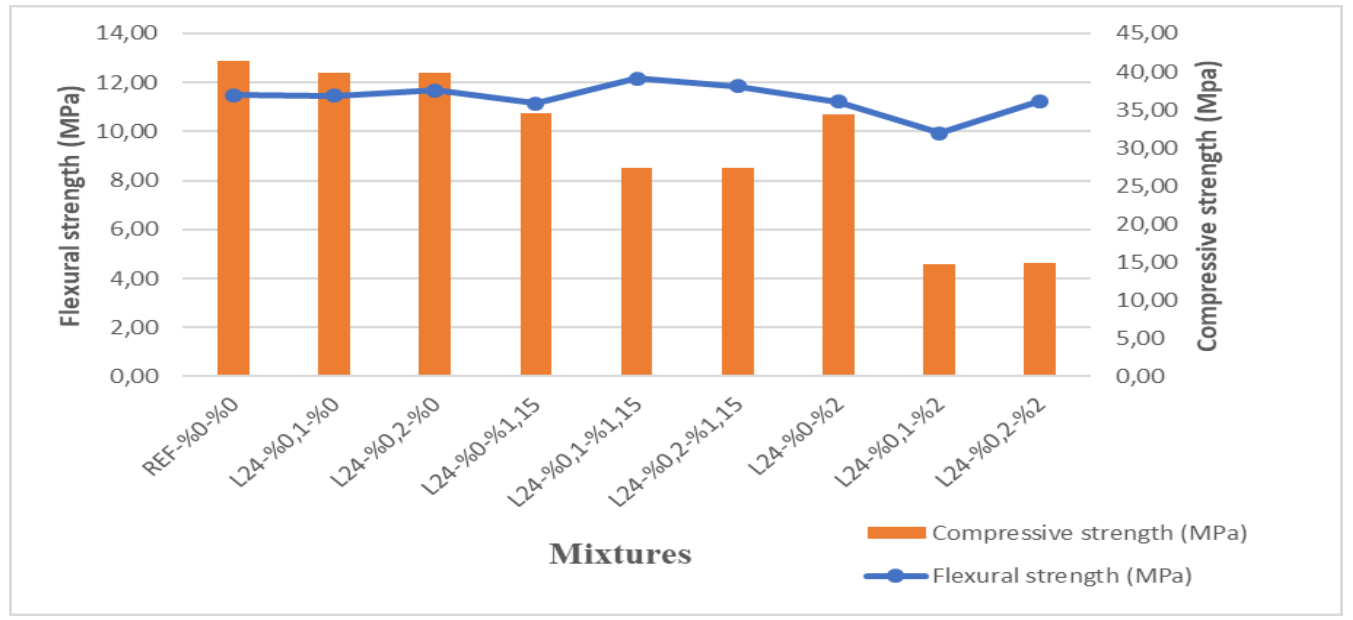

Figure 2. Compressive and flexural strength results

\subsubsection{UPV}

UPV values of mortar samples are shown in Figure 3. In the test, the transit time of ultrasonic sound through the specimen was measured. The samples with the dimensions of $4 \times 4 \times 16 \mathrm{~cm}$ were tested in terms of UPV. During the experiment, the transmission time was measured, and the length of the transmission path was divided by this value to calculate the ultrasonic pulse velocity. UPV values varied between $4.37-4.51 \mathrm{~mm} / \mu \mathrm{s}$. As the UPV fiber ratio increased, it was observed that the speed decreased, while the water impermeability added increased in speed. 


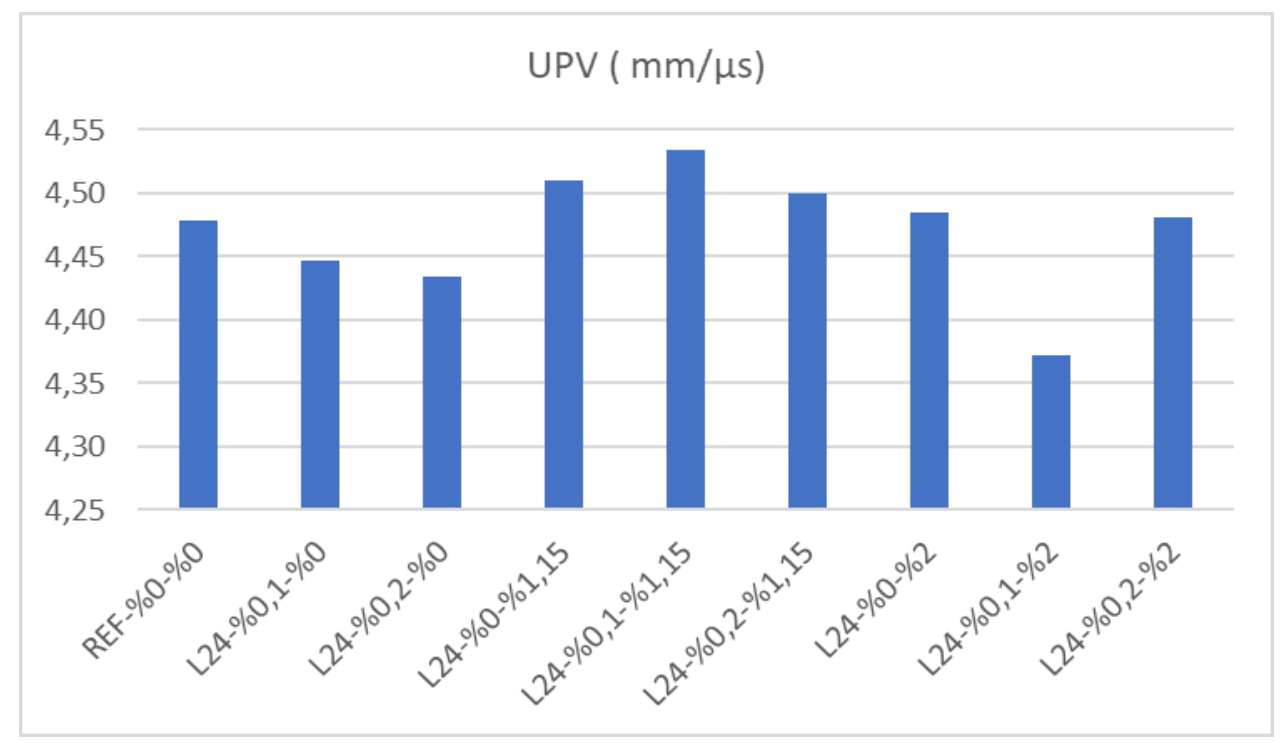

Figure 3. Results of UPV values of mortar samples

\subsubsection{Splitting Tensile Strength}

Splitting tensile strength values of mortar samples are shown in Figure 4. Splitting tensile test has been carried out in accordance with "TS EN 12390-6" [23]. Results in the tensile strength test in split increase compared to the reference samples. As the fiber ratio increased, the split tensile strength increased by $20 \%$ compared to the reference sample. There was a $50 \%$ increase compared to the reference sample in the series using impermeability additives.

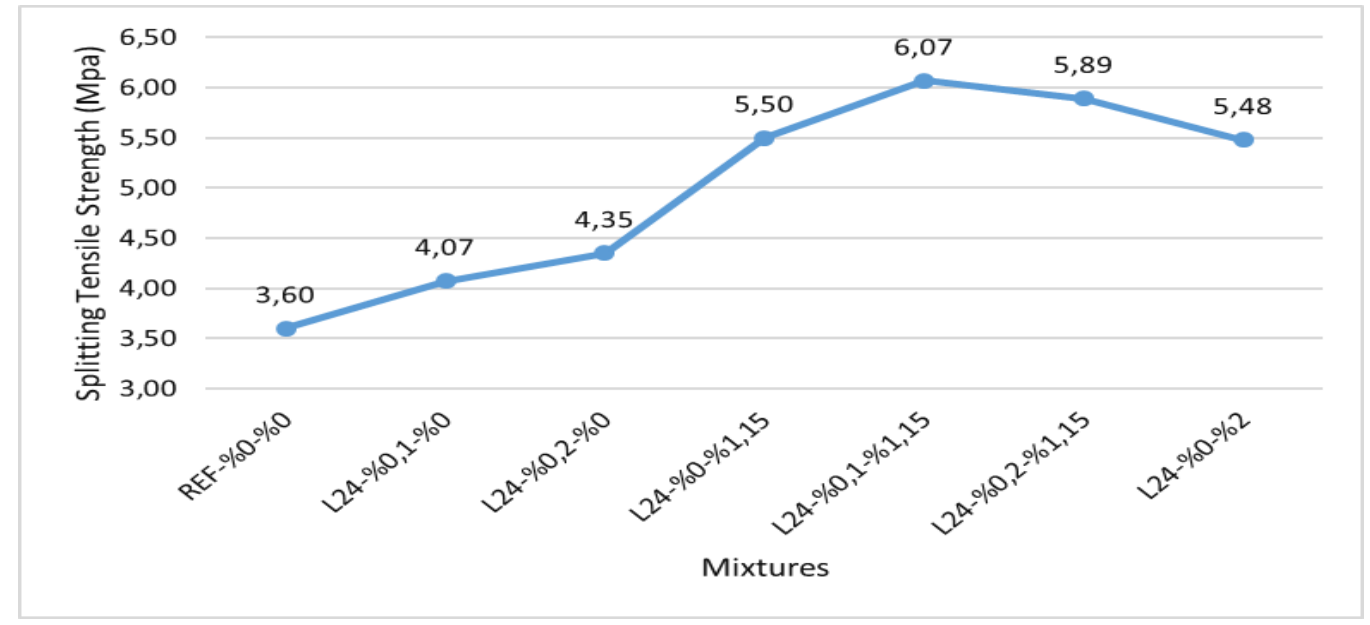

Figure 4. Results of splitting tensile strength values of mortar samples

\subsubsection{Determination of water processing depth under pressure}

The determination of water penetration depth under pressure was performed in accordance with the standard of TS EN 12390-8 [24]. Water treatment depth values of mortar samples are shown in Figure 5. While the water height in the reference sample was $12.33 \mathrm{~mm}$, the lowest pressure water processing depth was measured as $10.67 \mathrm{~mm}$ in L24-0.2\% - $0 \%$ series. It is the series in which the water processing depth of $10.67 \mathrm{~mm}$ is the glass fiber ratio of $0.2 \%$. This situation shows that the increase in fiber ratio leads to a decrease in water penetration depth. The depth of water under pressure was measured with the highest $13.38 \mathrm{~mm}$ in L24-\% 0-2 series. 


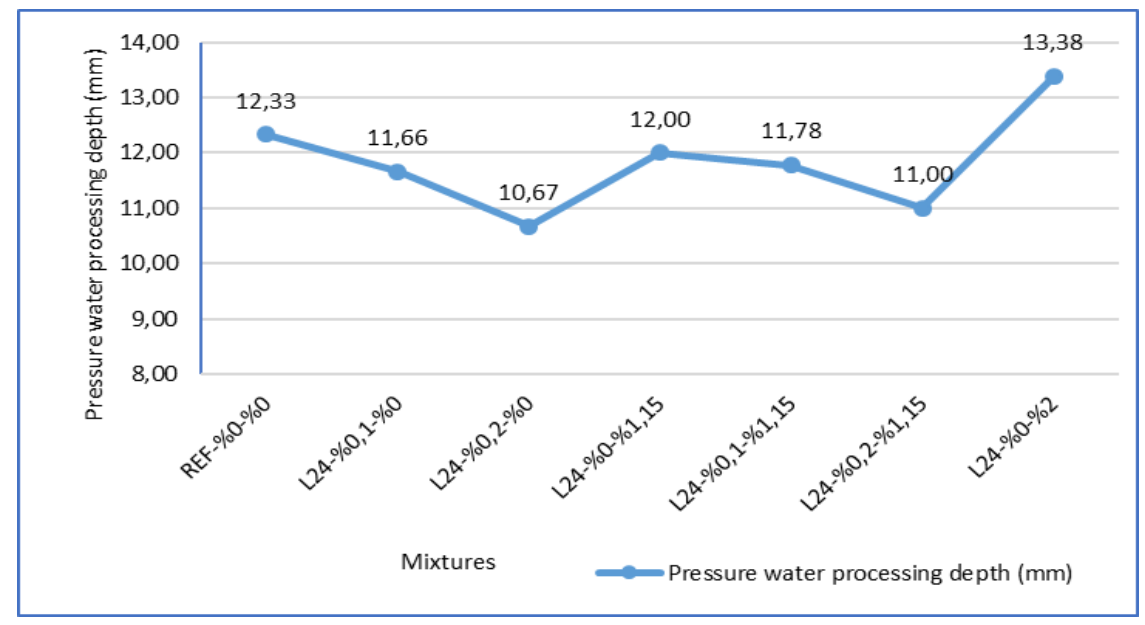

Figure 5. Results of water treatment depth values of mortar samples

\section{Conclusions}

In this study, the mechanical and permeability properties of glass fiber reinforced mortars were investigated. The study shows an improvement in mechanical properties for glass fiber reinforced mortar. The conclusions obtained from the experimental study are listed below:

1. When examined in terms of workability, the flow diameter decreased as the fiber ratio and impermeability contribution increased, the flow value decreased as the impermeability contribution increased.

2. A decrease in compressive strength was observed in series where fiber glass and impermeability additive were used together. The use of fiber glass and impermeability additive did not make any changes in terms of flexural strength.

3. In the series where the fiber glass is used at a rate of $0.1 \%$ by volume, the split tensile strength increased by $13 \%$ compared to the reference, while the split tensile strength increased by $20 \%$ compared to the reference when it was used at a rate of $0.2 \%$. Glass fiber can be used in certain proportions in mortars where high tensile strength is required.

4. The depth of pressurized water penetration in L24-0.2\% - $0 \%$ series where the fiber glass ratio is $0.2 \%$ has reduced by $14 \%$. The use of glass fiber positively affected the water penetration depth. In the mortar series where fiber glass and impermeability additive are used together, no significant change has been achieved in terms of pressurized water permeability.

5. As expected from fiber reinforced mortars the sudden collapse does not occur after crack formation.

\section{Conflict of interest}

The author declared no potential conflicts of interest with respect to the research, authorship, and/or publication of this article.

\section{Data Availability Statement}

All graphs and data obtained or generated during the investigation appear in the published article.

\section{Ethics}

There are no ethical issues after the publication of this manuscript.

\section{References}

[1] Newman, J., \& Choo, B. S. (Eds.). (2003). Advanced concrete technology 3: processes. Elsevier.

[2] Kabay, N. (2014). Abrasion resistance and fracture energy of concretes with basalt fiber. Construction and Building Materials, 50, 95-101. https://doi.org/10.1016/j.conbuildmat.2013.09.040

[3] B. Baradan, H. Yazıcı, S. Aydın. (2012). Beton, DEÜ Mühendislik Yayınları, İzmir.

[4] Nataraja, M., Dhang, N., \& Gupta, A. (2000). Toughness characterization of steel fiber-reinforced concrete by JSCE approach. Cement and Concrete Research, 30(4), 593-597. https://doi.org/10.1016/s0008-8846(00)00212-x 
[5] Yıldız, T., Yıldız, S., \& Keleştemur, O. (2011). Cam Lif Katkılı Betonda Filler Malzemesi Olarak Atık Mermer Tozunun Kullanılabilirliğinin Araştırılması. e-Journal of New World Sciences Academy, 6(4),1A0239.

[6] B. Bahadır. (2007), Concrete Fracture Toughness Impact of Life, SAE Institute of Science and Technology, Construction Education Department, Istanbul, Turkey [MSc Dissertation Thesis].

[7] Demirel, B., \& Yazıcıŏlu, S. (2010, May). 'İnce Malzeme Olarak Kullanılan Atık Mermer Tozunun Betonun Mekanik Özelikleri Üzerine Etkisi. In International Sustainable Buildings Symposium, Bildiriler Kitab1 (pp. 173 176).

[8] Yehia, S., Douba, A., Abdullahi, O., \& Farrag, S. (2016). Mechanical and durability evaluation of fiberreinforced self-compacting concrete. Construction and Building Materials, 121, 120-133. https://doi.org/10.1016/j.conbuildmat.2016.05.127

[9] Supit, S. W. M., \& Shaikh, F. U. A. (2014). Durability properties of high volume fly ash concrete containing nano-silica. Materials and Structures, 48(8), 2431-2445. https://doi.org/10.1617/s11527-014-0329-0

[10] Shaikh, F. U., \& Supit, S. W. (2015). Compressive strength and durability properties of high volume fly ash (HVFA) concretes containing ultrafine fly ash (UFFA). Construction and Building Materials, 82, $192-205$. https://doi.org/10.1016/j.conbuildmat.2015.02.068

[11] Anandaraj, S., Rooby, J., Awoyera, P. O., \& Gobinath, R. (2019). Structural distress in glass fibre-reinforced concrete under loading and exposure to aggressive environments. Construction and building materials, 197, 862870. https://doi.org/10.1016/j.conbuildmat.2018.06.090

[12] Hemavathi, S., Sumil Kumaran, A., \& Sindhu, R. (2020). An experimental investigation on properties of concrete by using silica fume and glass fibre as admixture. Materials Today: Proceedings, 21, 456-459. https://doi.org/10.1016/j.matpr.2019.06.558

[13] Jonalagadda, K. B., Kumar Jagarapu, D. C., \& Eluru, A. (2020). Experimental analysis on supplementary cementitious materials with Alkali Resistant glass fibers. Materials Today: Proceedings, 27, 1569-1574. https://doi.org/10.1016/j.matpr.2020.03.209

[14] Sanjeev, J., \& Sai Nitesh, K. (2020). Study on the effect of steel and glass fibers on fresh and hardened properties of vibrated concrete and self-compacting concrete. Materials Today: Proceedings, 27, 1559-1568. https://doi.org/10.1016/j.matpr.2020.03.208

[15] Afroughsabet, V., \& Ozbakkaloglu, T. (2015). Mechanical and durability properties of high-strength concrete containing steel and polypropylene fibers. Construction and Building Materials, 94, 73-82. https://doi.org/10.1016/j.conbuildmat.2015.06.051

[16] Neville, A.M. (1996). Properties of Concrete, 4th Ed., Wiley \& Sons, New York.

[17] TS EN 196 -1. (2016). Methods of testing cement - Part 1: Determination of strength. Turkish Standard Institute, Ankara, Turkey.

[18] O. Karahan, C.D. Atis. The durability properties of polypropylene fiber reinforced fly ash concrete. Mater. \& Design, 32: 1044-1049, 2011. https://doi.org/10.1016/j.matdes.2010.07.011

[19] Shekarchi, M., Libre, N. A., Mehdipour, I., Sangtarashha, A., \& Shafieefar, A. (2008). Shrinkage of highly flowable mortar reinforced with polypropylene fibre. In The 3rd International Conference-ACF/VCA (pp. 210216).

[20] Sun, Z., \& Xu, Q. (2009). Microscopic, physical and mechanical analysis of polypropylene fiber reinforced concrete. Materials Science and Engineering: A, 527(1-2), 198-204. https://doi.org/10.1016/j.msea.2009.07.056

[21] Puertas, F., Amat, T., Fernández-Jiménez, A., \& Vázquez, T. (2003). Mechanical and durable behaviour of alkaline cement mortars reinforced with polypropylene fibres. Cement and Concrete Research, 33(12), 20312036. https://doi.org/10.1016/s0008-8846(03)00222-9

[22] Venkata Krishna Bhargava, V., Brahma Chari, K., \& Ranga Rao, V. (2020). Experimental investigation of M40 grade concrete with supplementary cementitious materials and glass fiber. Materials Today: Proceedings, 33, 519-523. https://doi.org/10.1016/j.matpr.2020.05.209

[23] TS EN 12390-6. (2010). Testing hardened concrete-Part 6: Tensile splitting strength of test specimens, Turkish Standard Institute, Ankara, Turkey.

[24] TS EN 12390-8. (2010). Testing hardened concrete-Part 8: Depth of penetration of water under pressure, Turkish Standard Institute, Ankara, Turkey. 